\title{
STRATEGI PEMBERANTASAN KORUPSI OLEH KEPOLISIAN NEGARA REPUBLIK INDONESIA (POLRI)
}

\author{
Armunanto Hutahaean ${ }^{1}$ dan Erlyn Indarti ${ }^{2}$ \\ ${ }^{1}$ Kepolisian Daerah (Polda) Metropolitan Jakarta Raya \\ Jl. Jenderal Sudirman Kav. 55 Jakarta Selatan \\ ${ }^{2}$ Fakultas Hukum Universitas Diponegoro \\ Jl. Prof. Soedarto, Tembalang, Semarang \\ antoht@yahoo.com
}

\begin{abstract}
The main tasks of the Indonesia National Police was mandated by the law \& regulation namely maintain of public orderliness and security, enforce the law and provide protection, safeguard, and public service. For implementation of the law enforcement, The Indonesia National Police was authorised by the law \& regulation for conducting preliminary investigation and investigation of all forms of criminal acts including the criminal act of corupption. This paper will discuss the problem of the role of the National Police in combating corruption in Indonesia, as well as how the strategy to eradicate corruption in Indonesia. The criminal acts of corruption that have occurred in Indonesia have permeated to all life sectors and cause a disaster for national economy. Therefore, in the context of eradicating the criminal act of corruption needs the extraordinary law enforcement, implement optimally, efficiently, professionally and modernly.
\end{abstract}

Keywords: Indonesian National Police; Investigation; Criminal Act of Corruption

\begin{abstract}
Abstrak
Tugas pokok Kepolisian Negara Republik Indonesia sebagaimana amanat Undang-Undang yaitu memelihara keamanan dan ketertiban masyarakat, menegakkan hukum, dan memberikan perlindungani, pengayoman, dan pelayanan kepada masyarakat,. Untuk melaksanaan tugas dibidang penegakan hukum, Polri diberi wewenang untuk melakukan Penyelidikan dan Penyidikan terhadap semua tindak pidana, termasuk perkara tindak pidana korupsi. Tulisan ini akan membahas permasalahan peran Polri dalam memberantas korupsi di Indonesia, serta bagaimana strategi pemberantasan tindak pidana korupsi di Indonesia. Pembahasan menunjukkan bahwa orupsi di Indonesia telah merasuki seluruh aspek kehidupan masyarakat, membawa bencana terhadap perekonomian nasional. Untuk itu dalam rangka pemberantasan tindak pidana korupsi perlu dilakukan penegakan hukum yang luar biasa, dilaksanakan secara optimal dan profesional serta modern.
\end{abstract}

Kata Kunci: Polri; Penyidikan; Tindak Pidana Korupsi

\section{A. Pendahuluan}

Indonesia sebagai negara hukum tidak terlepas dari permasalahan-permasalahan yang dapat merusak konsep negara hukum tersebut, termasuk merusak cita-cita negara hukum itu sendiri. Salah satu permasalahan yang dapat merusak konsep negara hukum itu adalah permasalahan korupsi. Tindak pidana korupsi yang terjadi di Indonesia telah menjamur pada berbagai sektor dan juga kekuasaan eksekutif, legislatif dan yudikatif bahkan sektor swasta. Akibat buruk dari korupsi adalah lahirnya 
kesenjangan ekonomi dan lahirnya ketidakadilan serta ketidakmerataan pendapatan serta buruknya fasilitas dan infrastruktur kepentingan umum (Indarti, 2010, p. 40). Menurut Natanga Surbakti (2004), merebaknya praktik korupsi di Indonesia serta lemahnya kualitas kerja penegak hukum secara nasional juga telah berimbas pada kurang terpenuhinya hak-hak kolektif masyarakat, khususnya hak atas kesejahteraan, pembangunan dan kemajuan ekonomi.

Menjamurnya korupsi yang terjadi tentunya harus diimbangi dengan dilakukannya penegakan hukum yang komprehensif baik melalui hukum pidana maupun melalui saluran hukum pidana. Pencegahan dan penanggulangan kejahatan dilakukan dengan pendekatan integral antara kebijakan penal dengan kebijakan non penal. Kebijakan penal memiliki beberapa keterbatasan dan kelemahan yakni bersifat pragmatis, individualistik, lebih bersifat represif dan harus didukung dengan infrastruktur yang memerlukan biaya tinggi. Suteki mengatakan, bahwa dalam hukum modern, penggunaan hukum sebagai sarana rekayasa masyarakat (law as a tool of social engineering) dilakukan dengan melibatkan para pembuat hukum dengan merumuskan sanksi sebagai sarana penegakan hukum. Penegakan hukum tersebut dilakukan untuk mewujudkan perubahan yang efektif di dalam masyarakat (Bunga, 2019, p. 11).

Di bawah ini disajikan data Indeks Persepsi Korupsi Indonesia dari tahun 2012 hingga tahun 2019 menurut Transparancy International:
Tabel 1.

Indeks Persepsi Korupsi Indonesia Tahun 2012 s.d. 2019

\begin{tabular}{|c|c|c|c|}
\hline No. & Tahun & $\begin{array}{c}\text { Indeks } \\
\text { Persepsi } \\
\text { Korupsi } \\
\text { (IPK) } \\
\end{array}$ & Keterangan \\
\hline 1 & 2012 & 32 & $\begin{array}{l}\text { Peringkat } 118 \\
\text { dari } 176 \\
\text { negara }\end{array}$ \\
\hline 2 & 2013 & 32 & $\begin{array}{l}\text { Peringkat } 114 \\
\text { dari } 177 \\
\text { negara }\end{array}$ \\
\hline 3 & 2014 & 34 & $\begin{array}{l}\text { Peringkat } 88 \\
\text { dari } 168 \\
\text { negara }\end{array}$ \\
\hline 4 & 2015 & 36 & $\begin{array}{l}\text { Peringkat } 90 \\
\text { dari } 180 \\
\text { negara }\end{array}$ \\
\hline 5 & 2016 & 37 & $\begin{array}{l}\text { Peringkat } 90 \\
\text { dari } 180 \\
\text { negara }\end{array}$ \\
\hline 6 & 2017 & 37 & $\begin{array}{l}\text { Peringkat } 96 \\
\text { dari } 180 \\
\text { negara }\end{array}$ \\
\hline 7 & 2018 & 38 & $\begin{array}{l}\text { Peringkat } 89 \\
\text { dari } 180 \\
\text { negara }\end{array}$ \\
\hline 8 & 2019 & 40 & $\begin{array}{l}\text { Peringkat } 85 \\
\text { dari } 180 \\
\text { negara }\end{array}$ \\
\hline
\end{tabular}

Kepolisian Negara Republik Indonesia (yang selanjutnya disebut Polri) sebagai salah satu aparat penegak hukum dalam sistem peradilan pidana terpadu memiliki peran yang sangat penting dalam penegakan hukum pidana, salah satunya dalam melakukan pemberantasan tindak pidana korupsi. Dalam Undang-Undang No. 2 Tahun 2002 tentang Polri Pasal 2 disebutkan bahwa fungsi kepolisian adalah menjalankan salah satu fungsi pemerintahan negara dalam tugas penegakan hukum selain perlindungan, pengayoman dan pelayanan masyarakat. Sementara dalam Pasal 14 ayat (1) huruf g mengatakan bahwa polisi berwenang melakukan penyidikan tindak pidana yang 
sebelumnya didahului oleh tindakan penyelidikan oleh penyelidik (Rahardi, 2007, p. 27).

Demikian halnya terhadap tindak pidana korupsi. Dalam upaya pemberantasan tindak pidana korupsi sebagai proses penegakan hukum, langkah pertama yang dilakukan oleh Polri sebagai subsistem peradilan pidana adalah melakukan penyelidikan yang dilakukan oleh penyelidik. Jika dalam penyelidikan ditemukan adanya dugaan tindak pidana korupsi, maka langkah selanjutnya adalah melakukan penyidikan oleh penyidik (Muhammad, 1999, p. 47)

Masyarakat berharap besar kepada Polri sebagai salah satu aparat penegak hukum yang diberi wewenang oleh undang-undang sebagai Penyidik dalam melakukan pemberantasan tindak pidana korupsi yang terjadi. Namun harus diakui bahwa penegakan hukum yang dilakukan oleh Polri dalam rangka pemberantasan korupsi belum mampu untuk mewujudkan Indonesia bebas dari korupsi. Melihat kenyataan tersebut, penulis sangat tertarik untuk membahas tentang upaya pemberantasan korupsi yang dilakukan oleh Polri. Meskipun cukup banyak kajian mengenai hal ini, tulisan ini menyajikan orisinalitas penulisan dalam ruang lingkup Polri sebagai salah satu institusi penegak hukum dalam kaitannya dengan pemberantasan tindak pidana korupsi di Indonesia. Oleh karena itu, penulis mengajukan dua pertanyaan yang akan dibahas dalam tulisan ini, yaitu: pertama bagaimana peran Polri dalam memberantas korupsi di Indonesia? Dan kedua, bagaimana strategi pemberantasan tindak pidana korupsi di Indonesia?

\section{B. Pembahasan}

\section{Peran Polri dalam Memberantas Korupsi di Indonesia}

\section{a. Pengertian Tindak Pidana Korupsi}

David H. Bayley, mendefinisikan Korupsi sebagai Perangsang (seorang pejabat pemerintah atau swasta) berdasarkan itikad buruk (seperti misalnya, suapan) agar ia melakukan pelanggaran kewajibannya (Scott \& Lubis, 1988, p. 86). Berdasarkan dokumen yang dikeluarkan oleh Transparency International, merumuskan pengertian korupsi sebagai berikut :

Corruption involves behavior on the part of officials in the public sector, whether politicians or civil servants, in wich they improperly and unlawfully enrich themselves, or those close to them, by the public power entrusted them. (Korupsi mencakup perilaku dari pejabat-pejabat disektor publik, apakah politikus atau pegawai negeri, dimana mereka secara tidak benar dan melanggar hukum memperkaya diri sendiri atau pihak lain yang dekat dengan mereka, dengan cara menyalahgunakan kewenangan publik yang dipercayakan kepada mereka).

Sedangkan menurut UndangUndang No. 31 Tahun 1999 tentang Pemberantasan Tindak Pidana Korupsi sebagaimana diubah menjadi UndangUndang No. 20 Tahun 2001, memuat beberapa pengertian korupsi yaitu sebagai berikut (Hutahaean, 2019, p. 32): 1) Pasal 2 ayat (1) : Setiap orang yang secara melawan hukum melakukan perbuatan memperkaya diri sendiri atau orang lain atau suatu korporasi yang dapat merugikan keuangan Negara atau perekonomian Negara; 2) Pasal 3 : Setiap orang yang dengan tujuan menguntungkan diri sendiri atau orang lain atau suatu korporasi, menyalahgunakan kewenangan, kesempatan, atau sarana yang ada padanya karena jabatan atau kedudukan yang dapat merugikan Keuangan Negara atau perekonomian Negara.

Selama ini istilah korupsi mengacu pada berbagai aktivitas/tindakan secara tersembunyi dan illegal untuk mendapatkan keuntungan demi 
kepentingan pribadi atau golongan. Dalam perkembangannya terdapat penekanan bahwa korupsi adalah tindakan penyalahgunaan kekuasaan (abuse of power) atau kedudukan publik untuk kepentingan pribadi. Sementara Huntington menyebutkan bahwa korupsi adalah perilaku menyimpang dari public official atau para pegawai dari norma-norma yang diterima dan dianut oleh masyarakat dengan tujuan untuk memperoleh keuntungankeuntungan pribadi. Alatas mengemukakan pengertian korupsi dengan menyebutkan benang merah yang menjelujuri dalam aktivitas korupsi, yaitu subordinasi kepentingan umum di bawah kepentingan tujuantujuan pribadi yang mencakup pelanggaran norma-norma, tugas dan kesejahteraan umum, dibarengi dengan kerahasiaan, pengkhianatan, penipuan dan kemasa-bodohan yang luar biasa akan akibat-akibat yang diderita oleh masyarakat (Chaerudin, Dinar, \& Fadillah, 2008, p. 2).

Perbuatan pidana dapat diklasifikasikan sebagai perbuatan korupsi apabila perbuatan pidana tersebut memenuhi empat (4) unsur, yaitu (Kurniawan, 2015, p. 21): 1) Terdapat pelaku tindak pidana korupsi, dapat berupa perseorangan, sekelompok orang atau korporasi; 2) Perbuatan tersebut menguntungkan atau memperkaya dirinya sendiri, orang lain atau korporasi; 3) Perbuatan tersebut melanggar hukum atau menyalahgunakan kewenangannya; 4) Perbuatan tersebut telah merugikan negara maupun dapat merugikan keuangan negara atau perekonomian negara.

\section{b. Pengertian Penyelidik dan Penyidik serta Kewenangannya}

Berdasarkan Undang-Undang Nomor 8 Tahun 1981 tentang Hukum Acara Pidana, Polisi ditempatkan sebagai Penyidik dalam menangani tindak pidana yang sekaligus juga sebagai lembaga penegak hukum yang langsung berhadapan dengan penanggulangan kejahatan dalam masyarakat (Raharjo, 2011). Salah satu kiprah polisi dalam kedudukannya sebagai Penyidik tindak pidana adalah perannya di dalam sistem peradilan yang disalurkan melalui keterlibatannya sebagai salah satu komponen penegak hukum diantara penegak hukum lainnya (Indarti, 2018, p. 8). Apabila Sistem Peradilan Pidana digambarkan sebagai lingkaran yang berlapis-lapis, maka sebagai salah satu komponen penegak hukum, Polisi menempati posisi lapisan terluar (Indarti, 2018, p. 8).

Dalam Undang-Undang Nomor 8 Tahun 1981 Pasal 4 ayat (1) disebutkan bahwa Penyelidik adalah setiap pejabat Polisi Negara Republik Indonesia. Adapun kewenangan Penyelidik dalam Pasal 5 yaitu: 1) Karena kewajibannya mempunyai wewenang: (a) Menerima laporan atau pengaduan dari seseorang tentang adanya tindak pidana, (b) Mencari keterangan dan barang bukti, (c) Menyuruh berhenti seorang yang dicurigai dan menyatakan serta memeriksa tanda pengenal diri, (d) Mengadakan tindakan lain menurut hukum yang bertanggung jawab; 2) Atas perintah Penyidik dapat melakukan tindakan berupa: (a) Penangkapan, larangan meninggalkan tempat, penggeledahan dan penyitaan, (b) Pemeriksaan dan penyitaan surat, (c) Mengambil sidik jari dan memotret seorang, (d) Membawa dan menghadapkan seorang pada penyidik.

Pasal 6 ayat (1) Undang-Undang Nomor 8 Tahun 1981 tentang Kitab Undang-Undang Hukum Acara Pidana (KUHAP) disebutkan bahwa Penyidik adalah: a) Pejabat Polisi Negara Republik Indonesia; b) Pejabat Pegawai Negeri Sipil tertentu yang diberi wewenang khusus oleh undang-undang.

Kewenangan Penyidik sebagaimana tertulis dalam Pasal 7 ayat 
(1) KUHAP adalah sebagai berikut: 1) Menerima laporan atau pengaduan dari seseorang tentang adanya tindak pidana; 2) Melakukan tindakan pertama pada saat di tempat kejadian; 3) Menyuruh berhenti seorang tersangka dan memeriksa tanda pengenal diri tersangka; 4) Melakukan penangkapan, penahanan, penggeledahan, dan penyitaan; 5) Melakukan pemeriksaan dan penyitaan surat; 6) Mengambil sidik jari dan memotret seseorang; 7) Memanggil orang untuk didengar dan diperiksa sebagai tersangka atau saksi; 8) Mendatangkan orang ahli yang diperlukan dalam hubungannya dengan pemeriksaan perkara; 9) Mengadakan penghentian penyidikan; 10) Mengadakan tindakan lain menurut hukum yang bertanggung jawab.

Tugas dan tanggung jawab penyidik adalah membuat berita acara, menyerahkan berkas perkara kepada penuntut umum, dimana Penyerahan berkas perkara ini dilakukan yaitu pada tahap pertama penyidik hanya menyerahkan berkas perkara. Pada tahap kedua, dalam hal penyidikan sudah dianggap selesai, penyidik menyerahkan tanggung jawab atas tersangka dan barang bukti kepada penuntut umum.

Dalam melaksanakan perannya sebagaimana tertuang dalam Pasal 14 Undang-Undang Nomor 2 Tahun 2002 tentang Kepolisian Negara Republik Indonesia, pada dasarnya Polisi tidak hanya berperan sebagai penegak hukum yang merupakan salah satu komponen dalam sistem peradilan pidana, tetapi juga berperan dalam memelihara keamanan dan ketertiban masyarakat serta berperan sebagai Pelindung, Pengayom dan Pelayan masyarakat (Indarti, 2018, p. 8).

Cakupan peran yang dimainkan polisi dalam melaksanakan kontrol sosial demikian bukan saja bersifat represif tetapi juga preemtif dan preventif. Ada tiga kategori fungsional peran polisi dalam bekerja, yaitu meliputi: (1) Penegak Hukum (Pemberantas kejahatan); (2) Pemelihara ketertiban (Penjaga ketenangan); (3) Pelayanan masyarakat (bantuan masyarakat) (Indarti, 2018, p. 8).

Menurut Muladi, luasnya cakupan peran polisi sebenarnya merupakan perpaduan antara konsep authoritative intervention yang merupakan usaha yang setiap saat dan secara rutin dilakukan oleh polisi dalam rangka memelihara ketertiban dan keamanan dalam masyarakat dan konsep symbolic justice yang menekankan pada peran polisi dalam menunjukkan adanya tata hukum yang harus dihormati. Secara demonstratif, peran ini akan terlihat bila diterapkan kepada pelaku tindak pidana. Sebagai aparat penegak hukum dalam menjalankan fungsinya polisi wajib memahami azas-azas hukum, yaitu sebagai berikut (Muladi, 2002, p. 27):

1) Asas legalitas, dalam melaksanakan tugasnya sebagai penegak hukum wajib tunduk pada hukum; 2) Asas kewajiban, merupakan kewajiban polisi dalam menangani permasalahan dalam masyarakat yang bersifat diskresi, karena belum diatur dalam hukum; 3)

Asas partisipasi, dalam rangka mengamankan lingkungan masyarakat polisi mengkoordinasikan pengamanan Swakarsa untuk mewujudkan ketaatan hukum di kalangan masyarakat; 4) Asas preventif, selalu mengedepankan tindakan pencegahan daripada penindakan (represif) kepada masyarakat; 5) Asas subsidiaritas, melakukan tugas instansi lain agar tidak menimbulkan permasalahan yang lebih besar sebelum ditangani oleh instansi yang membidangi.

Sebagai penyelidik dan penyidik utama terhadap semua bentuk kejahatan, termasuk kejahatan yang merugikan keuangan negara (korupsi), dalam pelaksanaan tugasnya Polri dituntut untuk mampu mengetahui 
teknik dan modus operandi kejahatan korupsi serta mampu untuk mewujudkan keadilan, kemanfaatan dan kepastian hukum. sehingga dapat meningkatkan kepercayaan masyarakat kepada hukum dan terutama kepada polri. Dengan meningkatnya kepercayaan masyarakat terhadap hukum dan aparatnya (Polri), maka dapat menghilangkan sikap sinis masyarakat terhadap keberadaan Polri sebagai Penyelidik dan Penyidik perkara tindak pidana korupsi terutama sebagai penjaga gawang bekerjanya hukum (Rahardi, 2007, p. 32).

Dalam pemberantasan tindak pidana korupsi, peran Polri dipertegas dalam Instruksi Presiden Nomor 5 Tahun 2004 tanggal 9 Desember 2004 tentang Percepatan Pemberantasan Korupsi, huruf 11 butir 10 menginstruksikan khusus Kepala Kepolisian Negara Republik Indonesia untuk (Ali, 2016, p. 193): 1) Mengefektif dan efisienkan upayaupaya penyidikan terhadap tindak pidana korupsi untuk menghukum pelaku dan menyelamatkan uang negara; 2) Mencegah dan memberikan sanksi tegas terhadap penyalahgunaan wewenang yang dilakukan oleh anggota Kepolisian Negara Republik Indonesia dalam rangka penegakan hukum; 3) Meningkatkan kerjasama dengan Kejaksaan Republik Indonesia, Badan Pengawas Keuangan dan Pembangunan, Pusat Pelaporan dan Analisa Transaksi Keuangan, dan Institusi negara yang terkait dengan upaya penegakan hukum dan pengembalian kerugian Negara akibat tindak pidana korupsi.

Di bawah ini disajikan data pengungkapan kasus tindak pidana korupsi yang dilakukan oleh Polri pada tahun 2015, 2016, 2017:

Tabel 2.

Kasus Tindak Pidana Korupsi yang Diungkap Polri Tahun 2015 s.d. 2017

\begin{tabular}{cccccc}
\hline Tahun & $\begin{array}{c}\text { Crime } \\
\text { Total } \\
(\boldsymbol{C T})\end{array}$ & $\begin{array}{c}\text { Crime } \\
\text { Clearence } \\
(\boldsymbol{C C})\end{array}$ & $\begin{array}{c}\text { Dalam } \\
\text { Proses }\end{array}$ & $\begin{array}{c}\text { Kerugian Negara } \\
(\text { Rp) }\end{array}$ & $\begin{array}{c}\text { Keuangan Negara } \\
\text { diselamatkan } \\
(\text { Rp) }\end{array}$ \\
\hline 2015 & 1816 & 1021 & 795 & $1.450 .809 .518 .362,00,-$ & $437.066 .578 .685,00,-$ \\
2016 & 1357 & 952 & 405 & $1.277 .523 .201 .380,00,-$ & $176.915 .001 .057 .00,-$ \\
2017 & 1490 & 1108 & 382 & $2.987 .673 .849 .402,00,-$ & $1.887 .603 .913 .226,-$ \\
\hline
\end{tabular}

Sumber: Badan Reserse Kriminal Polri

Dari tabel data tersebut di atas, terlihat bahwa dari tahun 2015 hingga 2017, masih banyak kasus korupsi yang belum diselesaikan oleh penyidik. Tahun 2015 ada sebanyak 795 kasus yang belum selesai, 2016 ada 405 kasus dan 2017 sebanyak 382 kasus yang belum terselesaikan. Dari tabel juga terlihat bahwa penyelamatan keuangan negara yang dilakukan oleh Polri masih sangat kecil, belum sesuai dengan nilai kerugian negara yang terjadi. Kondisi tersebut bisa menimbulkan ketidakpercayaan masyarakat dan menimbulkan penilaian bahwa Polri belum berfungsi secara efektif dan efisien dalam memberantas korupsi.

\section{Strategi Pemberantasan Tindak Pidana Korupsi di Indonesia}

Dalam pemberantasan tindak pidana korupsi yang terjadi, selama ini di Indonesia lebih cenderung dilakukan melalui 
penggunaan kekuasaan dengan penjatuhan sanksi pidana. Sanksi pidana berarti suatu nestapa atau penderitaan yang ditimpakan kepada orang yang bersalah telah melakukan perbuatan yang dilarang oleh hukum pidana, dimana dengan adanya sanksi tersebut diharapkan orang tidak akan melakukan tindak pidana (Setiawan, 1999, p. 98).

Jika dilihat dari perspektif teori absolut atau teori pembalasan, dapat dibenarkan atas penjatuhan penderitaan berupa pemidanaan terhadap penjahat/koruptor. Negara berhak menjatuhkan pidana karena penjahat/koruptor tersebut telah melakukan penyerangan dan perkosaan pada hak dan kepentingan hukum (pribadi, masyarakat atau negara) yang telah dilindungi, oleh karena itu kepadanya harus diberikan pidana yang setimpal dengan perbuatan yang dilakukan. Salah satu penganut teori ini adalah Immanuel Kant. Menurut Kant bahwa menurut rasio, tiap kejahatan itu haruslah diikuti oleh suatu pidana (Chazawi, 2014, p. 157).

Merujuk pada teori tersebut, perkaraperkara tindak pidana korupsi yang ditangani oleh polri selalu diselesaikan melalui mekanisme pemidanaan. Baik terhadap tindak pidana korupsi yang bersumber dari aduan masyarakat dan juga dugaan tindak pidana korupsi yang bersumber dari temuan penyidik polri itu sendiri. Untuk aduan masyarakat terkait adanya dugaan tindak pidana korupsi, penyelidik melakukan pengumpulan bahan keterangan dengan tujuan untuk mengetahui apakah laporan tersebut sudah ditangani oleh penegak hukum lain (Kejaksaan dan KPK) atau belum, dan untuk mencari dokumendokumen pendukung serta pejabat-pejabat terkait yang akan dimintai keterangan. Setelah pengumpulan bahan keterangan dilakukan, dilanjutkan dengan kegiatan penyelidikan. Apabila dalam penyelidikan tidak ditemukan adanya peristiwa tindak pidana korupsi, maka atas aduan tersebut akan dihentikan penyelidikannya. Namun apabila ditemukan adanya peristiwa tindak pidana korupsi dalam penyelidikannya, maka terhadap aduan tersebut akan ditingkatkan ke penyidikan guna dilakukan pemberkasan atas perkara tindak pidana korupsi tersebut. Penghentian penyelidikan dan peningkatan status dari penyelidikan ke tingkat penyidikan dilakukan melalui mekanisme gelar perkara.

Pemberantasan tindak pidana korupsi, selain menjadi tanggung jawab Polri selaku bagian dari sistem peradilan pidana terpadu, juga menjadi bagian tanggung jawab Kejaksaan dan Komisi Pemberantasan Korupsi. Kejaksaan diberi wewenang untuk melakukan penyidikan terhadap kasus korupsi. Adapun yang menjadi dasar hukum kewenangan kejaksaan dalam melakukan penyidikan tindak pidana korupsi ialah: 1) Keputusan Presiden nomor 228 tahun 1967; 2) Undang-Undang Nomor 8 Tahun 1981 tentang Kitab Undang-Undang Hukum Acara Pidana (KUHAP) Pasal 284 Ayat (2); 3) Instruksi Presiden No. 15 Tahun 1983; 4) Keputusan Presiden Nomor 31 Tahun 1983, Pasal 44; 5) Putusan Mahkamah Agung Republik Indonesia nomor 1604/K/Pid/1990 tanggal 10 November 1994; 6) Pasal 30 Undang-Undang Nomor 16 Tahun 2004 tentang Kejaksaan; 7) Keputusan Presiden Nomor 11 Tahun 2005; 8) Fatwa KMA nomor KMA/102/III/2005 tanggal 9 maret 2005; 9) Putusan Mahkamah Konstitusi Nomor 16/P/UU-X/2012; 10) Inpres No. 5 Tahun 2004 tanggal 9 Desember 2004 tentang Percepatan Pemberantasan Korupsi huruf 11 butir 9 poin 1 berbunyi khusus Jaksa Agung Republik Indonesia diinstruksikan untuk mengoptimalkan upaya-upaya penyidikan terhadap tindak pidana korupsi untuk menghukum pelaku dan menyelamatkan uang Negara.

Harus diakui bahwa pemberantasan tindak pidana korupsi yang terjadi sampai sekarang belum dapat dilaksanakan secara optimal. Kepolisian ternyata belum bekerja secara optimal dalam memberantas korupsi. Hal itu dapat terlihat dari masih banyaknya perbuatan korupsi yang dilakukan baik oleh Legislatif, eksekutif dan yudikatif yang berdampak pada terjadinya kerugian keuangan negara, perekonomian negara serta 
terhambatnya program pembangunan nasional.

Dalam melaksanakan perannya memberantas tindak pidana korupsi, ada beberapa kendala yang dihadapi oleh Polri sehingga pemberantasan korupsi yang dilakukan belum bisa dilaksanakan secara efektif dan efisien. Kendala tersebut di antaranya berasal dari internal institusi Polri sendiri dan dari eksternal institusi Polri. Jika dilihat dari kendala internal, meliputi Sumber Daya Manusia (SDM) Polri. Ditinjau dari kualitas penyidik, ada penyidik yang belum memiliki pendidikan pengembangan spesialis (Dikbangspes) tindak pidana korupsi serta kurangnya pengetahuan tentang keuangan negara serta pengadaan barang dan jasa. Sedangkan dari segi jumlah dapat dilihat bahwa jumlah personil di Direktorat tindak pidana korupsi Bareskrim maupun di subdirektorat tindak pidana korupsi polda-polda jajaran yang ada masih belum ideal dengan kebutuhan organisasi. Saat ini, jumlah penyelidik dan penyidik tindak pidana korupsi Polri adalah sebanyak 2.978 orang. Sebanyak 103 orang merupakan penyidik di Direktorat Tindak Pidana Korupsi Badan Reserse Kriminal (Bareskrim) Polri yang berkedudukan di Mabes Polri, sisanya tersebar di 33 (tiga puluh tiga) Polda seluruh Indonesia.

Demikian juga dari segi anggaran yang diterima, Saat ini untuk menangani satu kasus korupsi, Polri hanya diberi alokasi anggaran penyelidikan dan penyidikan sebesar Rp. 208.000.000,- per kasus. Dalam proses penyelidikan/penyidikan terhadap perkara tindak pidana korupsi yang dilakukan oleh penyidik Polri, juga belum didukung oleh sarana dan prasarana yang memadai. Seperti ketersediaan alat penyadapan, dimana alat penyadapan ini sangat bermanfaat dalam mengungkap kasus-kasus korupsi, terutama dalam kasus penyuapan. Ketiadaan alat penyadapan tersebut juga karena sampai saat ini penyidik kepolisian tidak memiliki kewenangan untuk melakukan penyadapan sebagaimana halnya dengan Komisi Pemberantasan Korupsi.
Selain kendala internal yang dihadapai oleh penyidik Polri seperti yang dikemukakan di atas, ada juga kendala eksternal yang dihadapi oleh penyidik. Kendala eksternal tersebut berupa lamanya waktu penyidikan yang sangat tergantung dari kecepatan Auditor (BPK dan BPKP) dalam melakukan audit investigasi atau penghitungan kerugian kekayaan negara yang memakan waktu relatif lama yaitu antara 3 hingga 4 bulan. Selain itu prosedurprosedur yang ada di sistem peradilan pidana yang belum sejalan dengan upaya percepatan penyidikan tindak pidana korupsi. Seperti Jaksa Penuntut Umum (JPU) yang harus mengirimkan rencana penuntutan terlebih dahulu ke Kejaksaan Agung untuk dinilai atau diverifikasi sebelum diterbitkan P-21 (berkas dinyatakan lengkap) sehingga menyebabkan lamanya suatu berkas perkara dinyatakan lengkap (P21). Hal itu disebabkan adanya perbedaan persepsi antara Penyidik Polri dengan Jaksa penuntut umum dalam penanganan perkara korupsi, sehingga seringkali terjadi bolakbalik berkas perkara korupsi yang dikirimkan ke jaksa penuntut umum. Di dalam ketentuan Hukum Acara Pidana sendiri tidak jelas disebutkan berapa kali bolak-balik berkas perkara dikembalikan oleh Jaksa ke Penyidik hingga dinyatakan berkas tersebut sudah lengkap (P21).

Lazimnya, setiap perkara tindak pidana korupsi yang telah mendapatkan putusan dari pengadilan, maka terhadap pelakunya akan dipidana juga dengan Tindak Pidana Pencucian Uang (TPPU). Hal ini dikandung maksud untuk mengetahui aliran atau penempatan harta kekayaan yang diperoleh dari hasil korupsi, sehingga memudahkan penegak hukum untuk melakukan penyitaan harta kekayaan tersebut dalam rangka mengembalikan seluruh kerugian keuangan negara yang disebabkan tindak pidana korupsi yang dilakukan tersebut.

Di akhir pembahasan ini, penulis perlu menyampaikan rekomendasi upaya pemberantasan korupsi oleh Polri sehingga pemberantasan korupsi yang dilakukan dapat lebih berjalan dengan efisien dan 
efektif, antara lain: 1) Dalam melakukan pemberantasan tindak pidana korupsi yang terjadi di Indonesia, agar lebih mengutamakan upaya pencegahan daripada pemidanaan. Hal ini didasari pada pemikiran penulis bahwa dengan gencarnya dilakukan pemidanaan terhadap para koruptor, ternyata tidak mampu memberi efek jera dan tidak mampu untuk memberi pesan atau peringatan keras kepada orang lain yang memiliki potensi yang sangat tinggi untuk melakukan korupsi agar tidak melakukan korupsi. Untuk itu agar dapat terlaksana upaya pencegahan tersebut secara efektif dan efisien, maka perlu dibentuk suatu Direktorat Pencegahan Tindak Pidana Korupsi pada Badan Reserse Kriminal Polri hingga ke tingkat Polda; 2) Agar dalam menangani perkara tindak pidana korupsi yang terjadi, penyidik hendaknya lebih mengutamakan pengembalian kerugian keuangan negara, mengingat selama ini proses pengembalian kerugian keuangan negara sangat kecil dibandingkan dengan kerugian yang ditimbulkan akibat perbuatan korupsi yang dilakukan, selain itu lamanya proses hukum yang harus ditempuh berdampak pada lamanya pengembalian kerugian keuangan tersebut dapat terlaksana.

\section{Simpulan}

Berdasarkan fakta-fakta yuridis, peran Polri dalam pemberantasan korupsi di Indonesia sangat nyata dan jelas. Hal itu dapat dilihat berdasarkan bunyi Pasal 6 Undang-Undang Nomor 8 Tahun 1981 tentang Hukum Acara Pidana, yang menyatakan bahwa Penyidik adalah Pejabat Polri dan Pejabat Pegawai Negeri Sipil tertentu yang diberi wewenang tertentu oleh undang-undang. Sebagai penyidik, Polri diberi wewenang untuk melakukan penegakan hukum terhadap semua perkara pidana yang ada, tidak terkecuali terhadap perkara korupsi. Pengungkapan kasus dan penyelesaian perkara korupsi yang diimbangi dengan penyelamatan asset yang dilakukan Polri merupakan salah satu wujud nyata dari terlaksananya peran sebagai penyidik dalam memberantas korupsi.
Dalam pemberantasan tindak pidana korupsi yang terjadi, selama ini lebih cenderung dilakukan melalui upaya penegakan hukum dengan mempidanakan para pelaku korupsi. Proses pemidanaan yang dilakukan ternyata kurang efektif dalam pemberantasan korupsi, hal itu dapat dilihat masih tingginya tingkat korupsi yang terjadi. Selain itu, pengembalian kerugian keuangan negara yang terjadi akibat perbuatan korupsi masih sangat rendah. Dan bahkan anggaran yang dikeluarkan untuk melakukan penegakan hukum terhadap suatu perkara korupsi lebih besar daripada hasil yang diperoleh. Proses pemidanaan dari mulai penyelidikan hingga penuntutan dan peradilan memakan waktu yang cukup lama, hal itu juga membuat proses pengembalian kerugian keuangan negara membutuhkan waktu yang relatif lama.

\section{DAFTAR PUSTAKA}

\section{Ali, M. (2016). Hukum Pidana Korupsi.} Yogyakarta: UII Press.

Bunga, D. (2019). Politik Hukum Pidana Terhadap Penanggulangan Cybercrime. Jurnal Legislasi Indonesia, 16(1), 1-15.

Chaerudin, C., Dinar, S. A., \& Fadillah, S. (2008). Strategi pencegahan \& penegakan hukum tindak pidana korupsi. Refika Aditama.

Chazawi, A. (2014). Pelajaran Hukum Pidana Bagian I. Depok: Rajagrafindo Persada.

Hutahaean, A. (2019). Lembaga Penyidik Dalam Sistem Peradilan Pidana Terpadu Di Indonesia. Jurnal Legislasi Indonesia, 16(1), 27-41.

Indarti, E. (2010). Diskresi dan Paradigma: Sebuah telaah filsafat hukum. Semarang: Fakultas Hukum Universitas Diponegoro.

Indarti, E. (2018). Profesionalisme Dan Performansi Pengemban Fungsi Utama Kepolisian Dalam Penegakan Hukum. Semarang: Tiga Media Pratama. 
Kurniawan, A. (2015). Korupsi di Indonesia: keuangan negara, birokrasi dan pengendalian intern: mewujudkan Indonesia bebas dari korupsi. Yogyakarta: Fakultas Ekonomi \& Bisnis UGM.

Muhammad, R. (1999). Agenda Reformasi Sistem Peradilan Pidana. Jurnal Hukum IUS QUIA IUSTUM, 6(11), 44-56.

Muladi, M. (2002). Demokratisasi, hak asasi manusia, dan reformasi hukum di Indonesia. Jakarta: Habibie Center.

Rahardi, P. (2007). Hukum kepolisian: profesionalisme dan reformasi Polri. Surabaya: Laksbang Mediatama.

Raharjo, T. (2011). Mediasi pidana dalam sistem peradilan pidana: suatu kajian perbandingan dan penerapannya di Indonesia. Yogyakarta: Buku Litera.

Scott, J. C., \& Lubis, M. (1988). Bunga Rampai Korupsi. LP3ES.

Setiawan, M. A. (1999). Kajian Kritis TeoriTeori Pembenaran Pemidanaan. Jurnal Hukum IUS QUIA IUSTUM, 6(11), 97107. 